\title{
Nutrient Level of a Young Tropical Hydroelectric Dam Reservoir in Sarawak, Malaysia
}

\author{
TECK-YEE LING ${ }^{*}{ }^{1}$, NORLIZA GERUNSIN $^{2}$, CHEN-LIN SOO $^{1}$, LEE NYANTI $^{1}$, SIONG- \\ FONG SIM $^{1} \&$ JONGKAR GRINANG ${ }^{1}$ \\ ${ }^{1}$ Faculty of Resource Science and Technology, Universiti Malaysia Sarawak, 94300 Kota Samarahan, \\ Sarawak, Malaysia; ${ }^{2}$ Universiti Teknologi MARA, Kota Samarahan Campus, Jalan Meranek, \\ 94300 Kota Samarahan, Sarawak, Malaysia \\ *Corresponding author: teckyee60@gmail.com
}

\begin{abstract}
Monitoring the nutrient level of a reservoir is crucial as excess nutrients can lead to hypoxia and fish kills in the reservoir. Hence, this study was carried out to examine the nutrient level of the Bakun reservoir, which is a newly built hydroelectric reservoir in Sarawak, Malaysia. Water samples were taken at five stations in the reservoir at three different depths (surface layer, $10 \mathrm{~m}$, and $20 \mathrm{~m}$ ) in November 2013. The present study demonstrated that Bakun reservoir contained low nitrite-nitrogen $(\approx 0.005 \mathrm{mg} / \mathrm{L})$ and nitrate-nitrogen $(\approx 0.005 \mathrm{mg} / \mathrm{L})$ concentrations but high five-day biochemical oxygen demand $(\approx 4.73 \mathrm{mg} / \mathrm{L})$ and organic Kjeldahl nitrogen $(\approx 0.16 \mathrm{mg} / \mathrm{L})$ concentrations indicating that organic pollution occurred in the reservoir. On the other hand, a mean total phosphorus concentration of $98.3 \mu \mathrm{g} / \mathrm{L}$ in the Bakun reservoir complied with the $200 \mu \mathrm{g} / \mathrm{L}$ standard value of Class II according to National Water Quality Standards in Malaysia. The nutrient level in the Bakun reservoir differed according to sampling stations and depths. Samplings stations located at Murum River downstream of the Murum dam construction site showed peak value of turbidity (182 FNU) and organic Kjeldahl nitrogen $(0.45 \mathrm{mg} / \mathrm{L})$ particularly at deeper water column. Batang Balui and Linau River were observed with higher five-day biochemical oxygen demand $(>6 \mathrm{mg} / \mathrm{L})$ compared to other stations. Station near to the Bakun hydroelectric dam contained relatively high nitrite-nitrogen and total phosphorus concentrations but low nitrate-nitrogen and organic Kjeldahl nitrogen concentrations. Anthropogenic activities such as floating house and Murum dam construction have influenced the nutrients level in the reservoir.
\end{abstract}

Keywords : Bakun hydroelectric reservoir, dam construction, nitrogen, phosphorus, turbidity

Copyright: This is an open access article distributed under the terms of the CC-BY-NC-SA (Creative Commons Attribution-NonCommercial-ShareAlike 4.0 International License) which permits unrestricted use, distribution, and reproduction in any medium, for non-commercial purposes, provided the original work of the author(s) is properly cited.

\section{INTRODUCTION}

Nutrient level of a reservoir is an important indicator as it indicates the health status of an ecosystem, which supports the life of aquatic organisms (Rabalais, 2002; Camargo et al., 2005; Camargo \& Alonso, 2006; Schneider et al., 2014). High nutrient content in organic or inorganic forms due to the anthropogenic input is the main cause of eutrophication that can lead to fish kills in the reservoir. The study of nitrite and nitrate concentrations in water is often overlooked, giving more importance to the study of ammonia due to the toxicity of unionized ammonia to aquatic organism. Nevertheless, algae bloom can also be induced by high level of nitrite and nitrate as phytoplankton is able to utilize different forms of nitrogen. High level of nitrite and nitrate in water can also cause considerable stress in aquatic organisms (Jensen, 2003; Das et al., 2004; Hamlin, 2006).
The nutrient level of a reservoir can change over time when it ages and continuously receives loads of pollutants (Rossel \& de la Fuente, 2015). As a young tropical hydroelectric reservoir in Sarawak, the Bakun reservoir covers approximately 1.5 million ha of catchment mainly the Balui River that is fed by three major tributaries, namely, Bahau River, Linau River and Murum River. The reservoir is surrounded by anthropogenic activities from timber harvesting and oil palm plantation to Murum dam construction, which is cascading to Bakun dam, making it susceptible to water quality degradation (Nyanti et al., 2012a; Nyanti et al., 2015; Ling et al., 2015).

Although the Bakun dam reservoir currently serves as a single-purpose hydropower dam, there is a growing interest to further explore the reservoir for recreation and aquaculture activities. 
In Sarawak, the freshwater cage culture activity is concentrated at one of the oldest reservoirs in Malaysia that is the Batang Ai hydroelectric dam reservoir in Lubok Antu. Previous studies have shown that aquaculture activities deteriorated the water quality of the reservoir (Ling et al., 2012; Nyanti et al., 2012b: Ling et al., 2013). On the other hand, Tasik Kenyir in Terengganu, which was mainly designed for hydroelectric power generation and flood control purposes, has been successfully developed for eco-tourism activities, yet the concentrations of dissolved inorganic phosphorus and silicon were still classified as Class I according to National Water Quality Standards (NWQS) in Malaysia (Suratman et al., 2015). Due to the environmental concerns from existing anthropogenic activities and the potential future developments of the Bakun reservoir, this study aimed to determine its nutrient level that could serve as baseline data for future evaluations of the impacts of increased anthropogenic activities.

\section{MATERIALS AND METHODS}

Sampling was conducted in the Bakun reservoir in November 2013 as illustrated in Figure 1. A total of five stations were selected and the GPS coordinates of the sampling stations were summarized in Table 1. The Bakun hydroelectric dam cascades with a new dam located upstream at the Murum River of which the construction was ongoing at the time of sampling. Triplicate water samples were collected at surface layer, $10 \mathrm{~m}$, and $20 \mathrm{~m}$ depths in the Bakun reservoir using a Van Dorn water sampler and transferred into cleaned acid-washed bottle. The depth of the reservoir was measured using a portable depth sounder (Speedtech). The corresponding turbidity was measured in situ using a turbidity meter (Martini Instrument, Mi 415). Besides, the depth profiles of $\mathrm{pH}$ and turbidity at Station 3 and 4, which were located downstream of the Murum dam construction site, were measured using a YSI 6820 V2 multi-parameter water quality sonde.

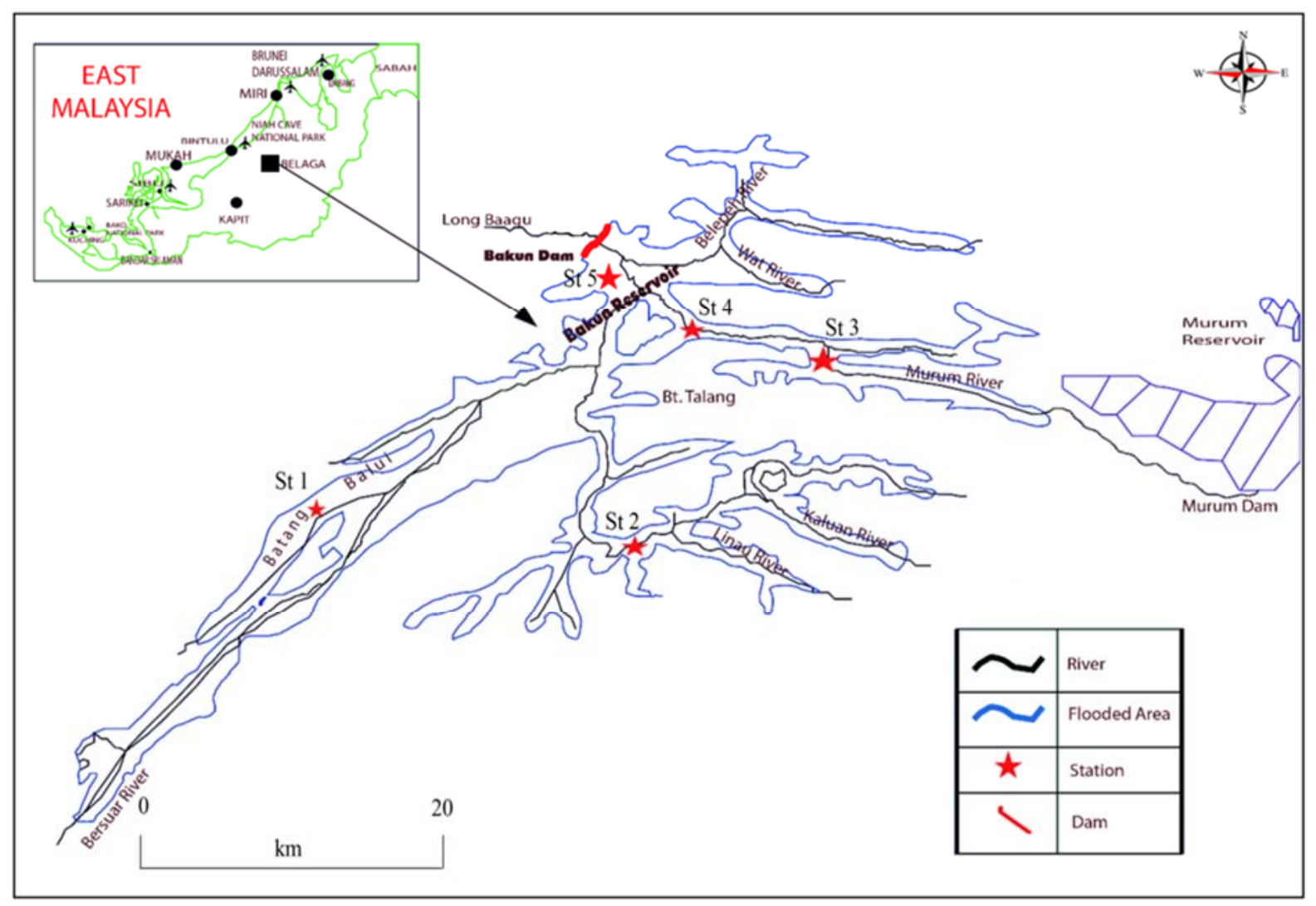

Figure 1. The study area and sampling stations in the Bakun reservoir. 
Table 1. The details of the sampling location and sampling time in the present study.

\begin{tabular}{ccc}
\hline Station & Date, Time & Location \\
\hline St $1\left(\mathrm{~N} \mathrm{02} 43^{\prime} 34.4^{\prime \prime}\right.$ E $\left.114^{\circ} 01^{\prime} 44.2^{\prime \prime}\right)$ & $6^{\text {th }}$ Nov 2013, 1.12pm & Batang Balui \\
St 2 $\left(\mathrm{N} \mathrm{02} 39^{\prime} 32.2^{\prime \prime}\right.$ E $\left.114^{\circ} 03^{\prime} 29.5^{\prime \prime}\right)$ & $6^{\text {th }}$ Nov 2013, 6.00pm & Linau River \\
St $3\left(\mathrm{~N} \mathrm{02} 42^{\prime} 59.8^{\prime \prime}\right.$ E $\left.114^{\circ} 09^{\prime} 43.8^{\prime \prime}\right)$ & $7^{\text {th }}$ Nov 2013, 11.05am & Upper part of Murum River \\
St $4\left(\mathrm{~N} \mathrm{02} 44^{\prime} 15.3^{\prime \prime}\right.$ E $\left.114^{\circ} 05^{\prime} 16.6^{\prime \prime}\right)$ & $7^{\text {th }}$ Nov 2013, 2.09pm & Lower part of Murum River \\
St $5\left(\mathrm{~N} \mathrm{02} 45^{\prime} 09.8^{\prime \prime}\right.$ E $\left.114^{\circ} 02^{\prime} 32.9^{\prime \prime}\right)$ & $7^{\text {th }}$ Nov 2013, 4.50pm & Near to the Bakun dam \\
\hline
\end{tabular}

Water samples were acidified to $\mathrm{pH}$ less than 2 at the field site for total phosphorus (TP) analysis using sulphuric acid. All samples were placed in an ice box at low temperature and transported to the laboratory for further analyses (Jenkins et al., 2005). All the water quality analyses were conducted according to standard methods (Jenkins et al., 2005; Hach, 2015). After five days of incubation of the sample, the five-day biochemical oxygen demand $\left(\mathrm{BOD}_{5}\right)$ concentration was determined as the difference between the initial and five-day DO content. The initial DO content was determined by using a YSI $6820 \mathrm{~V} 2$ multi-parameter water quality sonde in the field and increased by vigorous aeration if the DO value were low. Nitrite-nitrogen $\left(\mathrm{NO}_{2}^{-}-\mathrm{N}\right)$ and nitrate-nitrogen $\left(\mathrm{NO}_{3}^{-}-\mathrm{N}\right)$ concentrations were determined by diazotization method (low range) and cadmium reduction method, respectively after filtering through a $0.45 \mu \mathrm{m}$ glass fibre filter (Whatman GF/F). Organic Kjeldahl Nitrogen $(\mathrm{OKN})$ concentration was determined by Macro-Kjeldahl method where ammonia was removed from the water samples before digestion and distillation, and followed by Nessler's method. TP concentration was determined by ascorbic acid method after persulfate digestion of samples.

Comparison of water quality parameters including $\mathrm{BOD}_{5}, \mathrm{NO}_{2}^{-}-\mathrm{N}, \mathrm{NO}_{3}^{-}-\mathrm{N}, \mathrm{OKN}, \mathrm{TP}$, and turbidity among stations and depths in the Bakun hydroelectric reservoir were conducted using oneway ANOVA and Tukey's pairwise comparisons with 5\% significance level. One-way ANOVA was also used to compare transparency among stations, followed by a Tukey's test. Cluster analysis (CA) was used to investigate the grouping of the sampling stations with different depths by using the water quality parameters collected in the reservoir. Z-score standardization of the variables and Ward's method using Euclidean distances as a measure of similarity was used. The cluster was considered statistically significant at a linkage distance of more than $60 \%$ and the number of clusters was decided by the practicality of the outputs (Muangthong \& Shrestha, 2015). All the statistical analyses were carried out by using Statistical Software for Social Sciences (SPSS Version 22, SPSS Inc. 1995).

\section{RESULTS AND DISCUSSION}

Surface layer of $\mathrm{BOD}_{5}$ concentration of Bakun reservoir ranged from $3.77 \pm 0.19 \mathrm{mg} / \mathrm{L}$ to $6.16 \pm$ $0.11 \mathrm{mg} / \mathrm{L}$ in the present study. The lowest and the highest $\mathrm{BOD}_{5}$ concentrations were found at Station 4 and Station 1, respectively. Figure 2 illustrates that vertical distribution of $\mathrm{BOD}_{5}$ concentration in Bakun reservoir differed at different locations. According to Tukey's pairwise comparison, no significant difference ( $p$ value $>0.05)$ of $\mathrm{BOD}_{5}$ concentration was observed at Station 1 and 3 whereas $\mathrm{BOD}_{5}$ concentration at station 2 was significantly higher ( $p$-value $\leq 0.05)$ at a depth of $10 \mathrm{~m}$. Among the five stations, Station 1 and 2 contained significantly higher $\mathrm{BOD}_{5}$ concentration ( $p$-value $\leq 0.05)$ at all depths of the water column. The highest $\mathrm{BOD}_{5}$ concentration at surface water at Station $1(6.16 \mathrm{mg} / \mathrm{L})$ and at a depth of $10 \mathrm{~m}$ at Station $2(6.17 \mathrm{mg} / \mathrm{L})$ are classified as Class IV according to National Water Quality Standards (NWQS) in Malaysia (Department of Environment, 2015). The high $\mathrm{BOD}_{5}$ concentration at the two stations demonstrated the organic matter loading, which could probably originate from the floating house located at the upstream of Linau River. Human feces and food waste with high organic matter contribute substantial organic matter in the reservoir when the household wastewater is directly discharged into the reservoir (Ling et al., 2010). On the other hand, the lowest value of $2.91 \mathrm{mg} / \mathrm{L}$ at Station 4 
at a depth of $20 \mathrm{~m}$ is classified as Class II. Other than that, all $\mathrm{BOD}_{5}$ concentrations in the Bakun reservoir are classified as Class III indicating that the $\mathrm{BOD}_{5}$ concentrations are only good for more tolerant aquatic species (Table 2). The $\mathrm{BOD}_{5}$ concentration in November 2013 in the present study was higher than the $\mathrm{BOD}_{5}$ concentration $(0.37-4.32 \mathrm{mg} / \mathrm{L}$ ) in April 2013 (Nyanti et al., 2015). The elevated $\mathrm{BOD}_{5}$ concentration in the reservoir could be an indicator of the accumulation of organic matter in the Bakun reservoir over time. Besides, the variation of $\mathrm{BOD}_{5}$ concentration could also be due to the variability of rainfall amount during the different sampling period (Ling et al., 2017).

$\mathrm{NO}_{2}{ }^{-}-\mathrm{N}$ and $\mathrm{NO}_{3}{ }^{-}-\mathrm{N}$ concentrations were low in the Bakun reservoir, with a mean concentration of $0.005 \mathrm{mg} / \mathrm{L}$. The lowest $(\approx$ $0.002 \mathrm{mg} / \mathrm{L})$ and the highest $\mathrm{NO}_{2}^{-}-\mathrm{N}(\approx 0.007$ $\mathrm{mg} / \mathrm{L}$ ) concentration was observed at Station 4 and Station 5, respectively, which were significantly different from each other ( $p$-value $\leq 0.05)$. In contrast, Station 4 contained significantly higher $\mathrm{NO}_{3}{ }^{-}-\mathrm{N}$ concentration $\quad \approx$ $0.008 \mathrm{mg} / \mathrm{L}$ ) whereas Station 5 contained significantly lower $\mathrm{NO}_{3}{ }^{-}-\mathrm{N}$ concentration $(\approx 0.003 \mathrm{mg} / \mathrm{L})(p$-value $\leq 0.05)$. Overall, $\mathrm{NO}_{2}{ }^{-}$ $\mathrm{N}$ and $\mathrm{NO}_{3}^{-} \mathrm{-}$ concentrations did not vary significantly ( $p$-value $>0.05$ ) as depth increased at most of the stations in the Bakun reservoir except at the surface layer of Station 3 and 5. Station 3 contained significantly lower $\mathrm{NO}_{2}{ }^{-}-\mathrm{N}$ concentration but significantly higher $\mathrm{NO}_{3}{ }^{-} \mathrm{N}$ concentration in the surface water ( $p$-value $\leq$ 0.05 ). Station 5 exhibited an opposite trend where surface layer at station 5 was significantly higher in $\mathrm{NO}_{2}^{-}-\mathrm{N}$ concentration but significantly lower in $\mathrm{NO}_{3}{ }^{-} \mathrm{N}$ concentration ( $p$-value $\leq 0.05$ ). The low concentrations of $\mathrm{NO}_{2}{ }^{-}-\mathrm{N}$ and $\mathrm{NO}_{3}{ }^{-}-\mathrm{N}$ in the Bakun reservoir complied with the guideline values set by the Department of Environment, Malaysia and can be classified as Class II. The classification of $\mathrm{NO}_{2}^{-}-\mathrm{N}$ and $\mathrm{NO}_{3}^{-}-$ $\mathrm{N}$ as Class II indicates that their concentrations are good for sensitive aquatic species (Table 2). The $\mathrm{NO}_{2}^{-}-\mathrm{N}$ and $\mathrm{NO}_{3}^{-}-\mathrm{N}$ concentrations in the present study are within the range of $\mathrm{NO}_{2}^{-}-\mathrm{N}$ $(0.0003-0.0083 \mathrm{mg} / \mathrm{L})$ and $\mathrm{NO}_{3}{ }^{-} \mathrm{N}(0.003-$ $0.027 \mathrm{mg} / \mathrm{L}$ ) reported in April 2013 (Ling et al., 2016) in the Bakun reservoir. Figure 2 illustrates that OKN concentration was relatively consistent in the Bakun reservoir with a mean of $0.14 \mathrm{mg} / \mathrm{L}$ except a peak value of $0.45 \mathrm{mg} / \mathrm{L}$ at station 4 at a depth of $20 \mathrm{~m}$.

Table 2. The water classes and uses (Department of Environment, 2015).

\begin{tabular}{ll}
\hline Class & Uses \\
\hline Class I & Conservation of natural environment. \\
& Water Supply I - Practically no treatment necessary. \\
& Fishery I - Very sensitive aquatic species. \\
Class IIA & Water Supply II - Conventional treatment. \\
& Fishery II - Sensitive aquatic species. \\
Class IIB & Recreational use body contact. \\
Class III & Water Supply III - Extensive treatment required. \\
& Fishery III - Common,of economic value and tolerant species;livestock drinking. \\
Class IV & Irrigation \\
Class V & None of the above. \\
\hline
\end{tabular}

The construction of Murum dam contributes substantial OKN value in Station 3 and 4 which are located downstream of the construction site. Among all stations, Station 5 contained significantly lower $\mathrm{OKN}$ concentration $(\approx 0.12$ $\mathrm{mg} / \mathrm{L})$ at all three depths of the water column $(p-$ value $\leq 0.05)$. Generally, OKN concentration was found significantly higher $(p$-value $\leq 0.05$ ) at deeper water column at most of the stations, which is most probably due to the resuspension of the organic matter from the bottom sediment (Hayami et al., 2008). Lastly, TP concentration ranged from $76.1 \pm 6.3 \mu \mathrm{g} / \mathrm{L}$ to $120.1 \pm 6.3 \mu \mathrm{g} / \mathrm{L}$ in the Bakun reservoir. The lowest and the highest concentrations were observed at the surface water column of Station 3 and Station 5, respectively. Similar to OKN, TP concentration was significantly higher ( $p$-value $\leq 0.05)$ at the deeper water column at most of the stations except Station 5, which had no significant difference of TP concentration at all depths examined ( $p$-value $>0.05)$. In the present study, TP concentration complied with the Class II standard value of $200 \mu \mathrm{g} / \mathrm{L}$, which meets the requirement for sensitive aquatic species according to the NWQS (Department of Environment, 2015). 

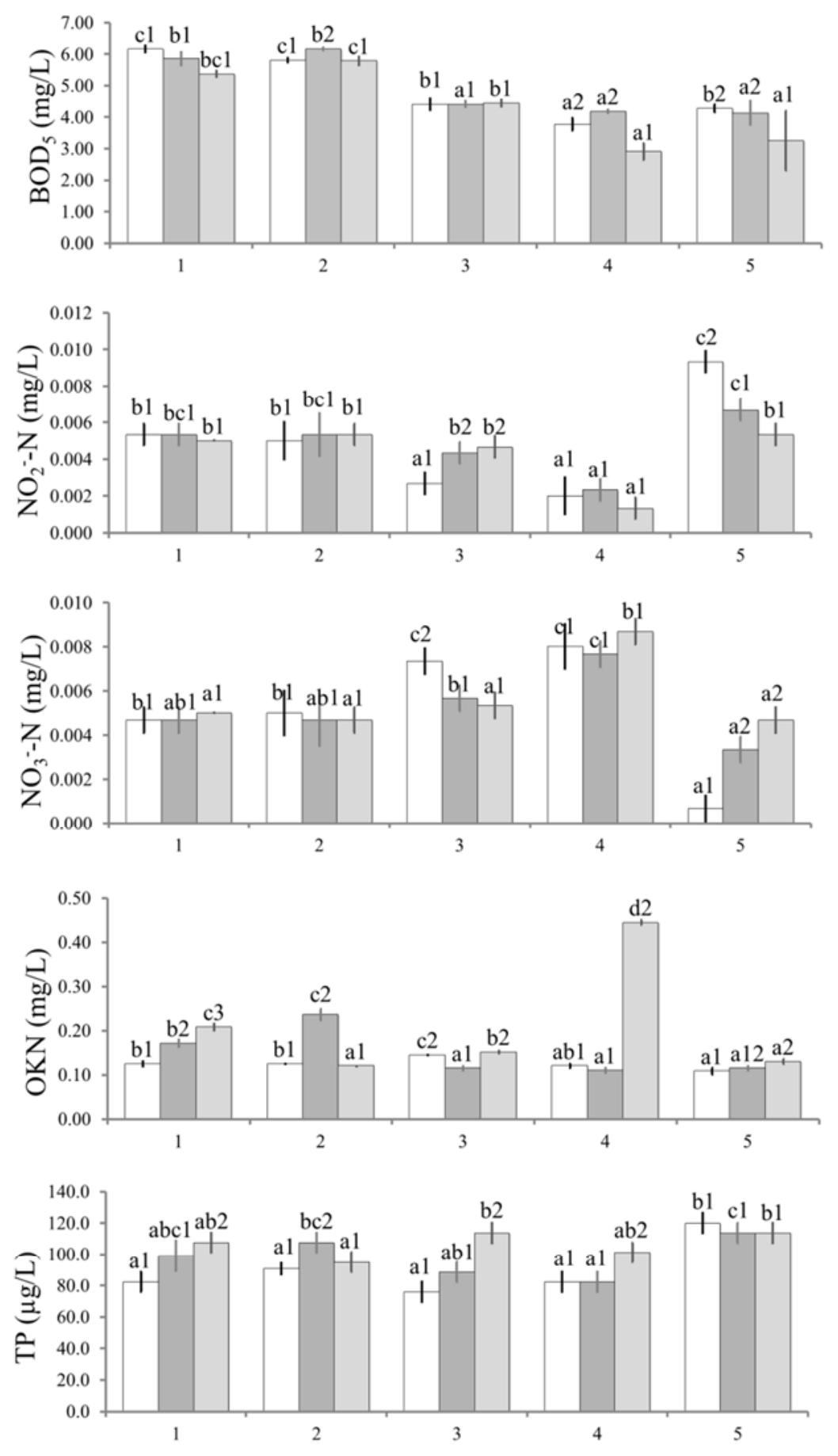

Station

\section{Legend $\square$ Surface layer $\square 10 \mathrm{~m} \quad \square 20 \mathrm{~m}$}

Figure 2. The distributions of five-day biochemical oxygen demand $\left(\mathrm{BOD}_{5}\right)$, nitrite-nitrogen $\left(\mathrm{NO}_{2}{ }^{-} \mathrm{-N}\right)$, nitratenitrogen $\left(\mathrm{NO}_{3}{ }^{-} \mathrm{-N}\right)$, Organic Kjeldahl Nitrogen $(\mathrm{OKN})$, and total phosphorus (TP) at three different depths (surface layer, 10, and $20 \mathrm{~m}$ ) of Bakun reservoir in November 2013. Bars at the same depth with same alphabet or bars at the same station with same number are not significantly different at $5 \%$ level of significance. 
The surface turbidity value of Bakun reservoir was low, ranging from $0.90 \pm 0.02 \mathrm{FNU}$ to 3.24 \pm 0.04 FNU with significant increase ( $p$-value $\leq$ $0.05)$ as the depth increased at all stations (Figure 3). The turbidity value increased up to $42.17-182.00 \mathrm{FNU}$ at a depth of $20 \mathrm{~m}$. High turbidity value as depth increased is most likely due to the settling and re-suspension of settled solids (Aris et al., 2014). Similar observation was also reported during the filling phase of the Bakun reservoir (Nyanti et al., 2012a) and 13 months after reaching its full supply level (Ling et al., 2016). The surface turbidity value in Bakun reservoir is classified as Class I but changed to Class II and/or exceeded the NWQS as depth increased particularly Station 3 and Station 4.
The turbidity value was significantly higher $(p$-value $\leq 0.05)$ at Station 3 and 4, which are located at Murum river. The land clearing activities coupled with dam construction at the upstream of Murum River accelerated the soil erosion and sedimentation where the suspended solids were transported into the reservoir during surface runoff and deposited at the bottom of the reservoir. On the other hand, the transparency value was high in the Bakun reservoir, ranging from $1.33 \pm 0.01 \mathrm{~m}$ to $4.20 \pm 0.08 \mathrm{~m}$, due to the low turbidity value at the surface. The transparency was significantly different ( $p$-value $\leq 0.05$ ) among the five stations in the Bakun reservoir with significantly higher transparency at Station 1 that corresponds to the lowest turbidity value in the station.

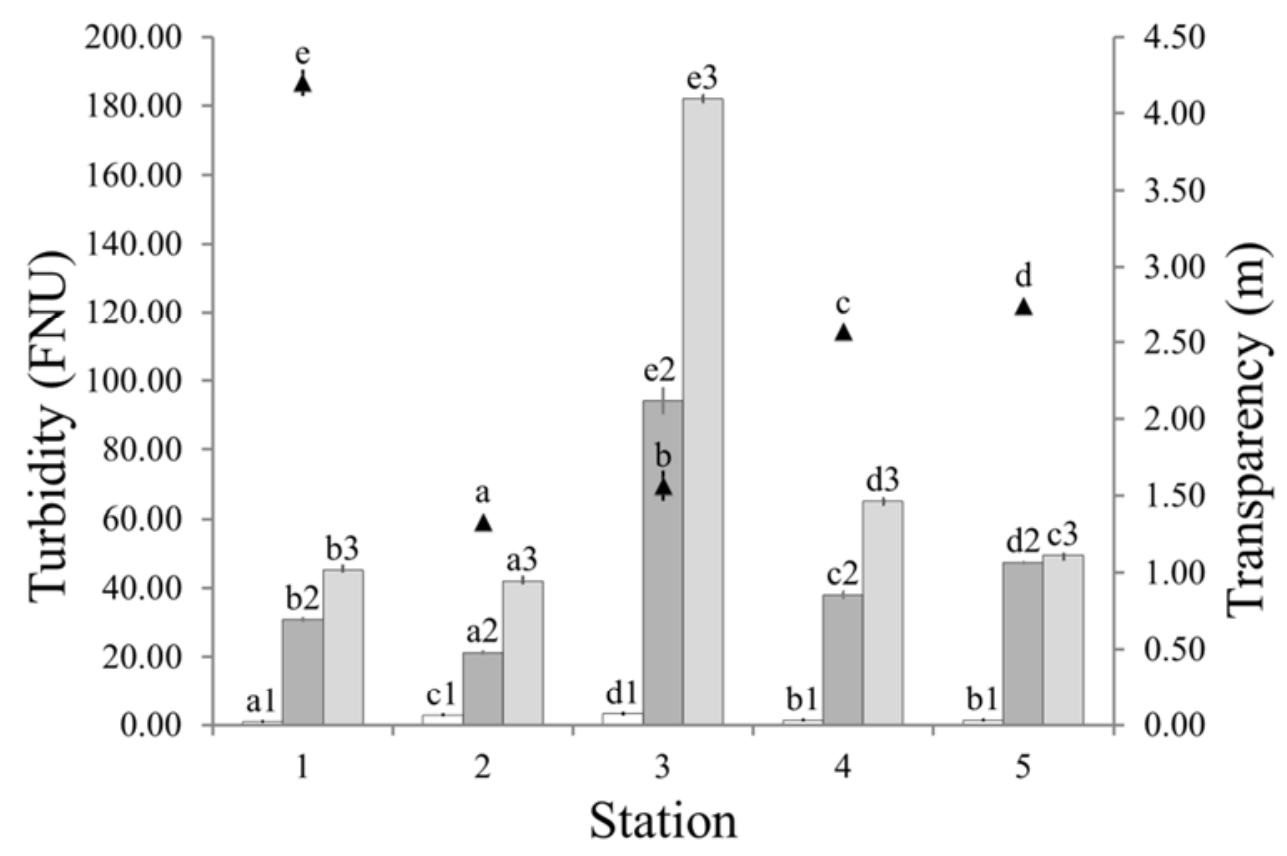

Legend $\square$ Surface layer $\square 10 \mathrm{~m} \quad \square 20 \mathrm{~m} \quad \boldsymbol{\Delta}$ Transparency

Figure 3. The distributions of transparency and turbidity at three different depths (surface layer, 10, and $20 \mathrm{~m}$ ) of Bakun reservoir in November 2013. Bars at the same depth with the same alphabet or bars at same station with the same number are not significantly different at $5 \%$ level of significance. 
Figure 4 illustrates the $\mathrm{pH}$ and turbidity depth profiles at Station 3 and 4, which are located downstream of the Murum dam that was under construction. The $\mathrm{pH}$ profile shows that $\mathrm{pH}$ decreased from 6.4 to 6.1 and 6.0 at Station 3 and Station 4, respectively as the depth increased and this is in a good agreement with the previous study (Ling et al., 2016). The $\mathrm{pH}$ value is classified as Class II.
On the other hand, the turbidity profile shows that the turbidity increased as the depth increased at both stations with the maximum value of 67 and 705 NTU achieved at Station 3 and Station 4, respectively at a depth of $22 \mathrm{~m}$. The low $\mathrm{pH}$ and high turbidity value at station 3 could be associated with the impact of the Murum dam construction on the downstream river.
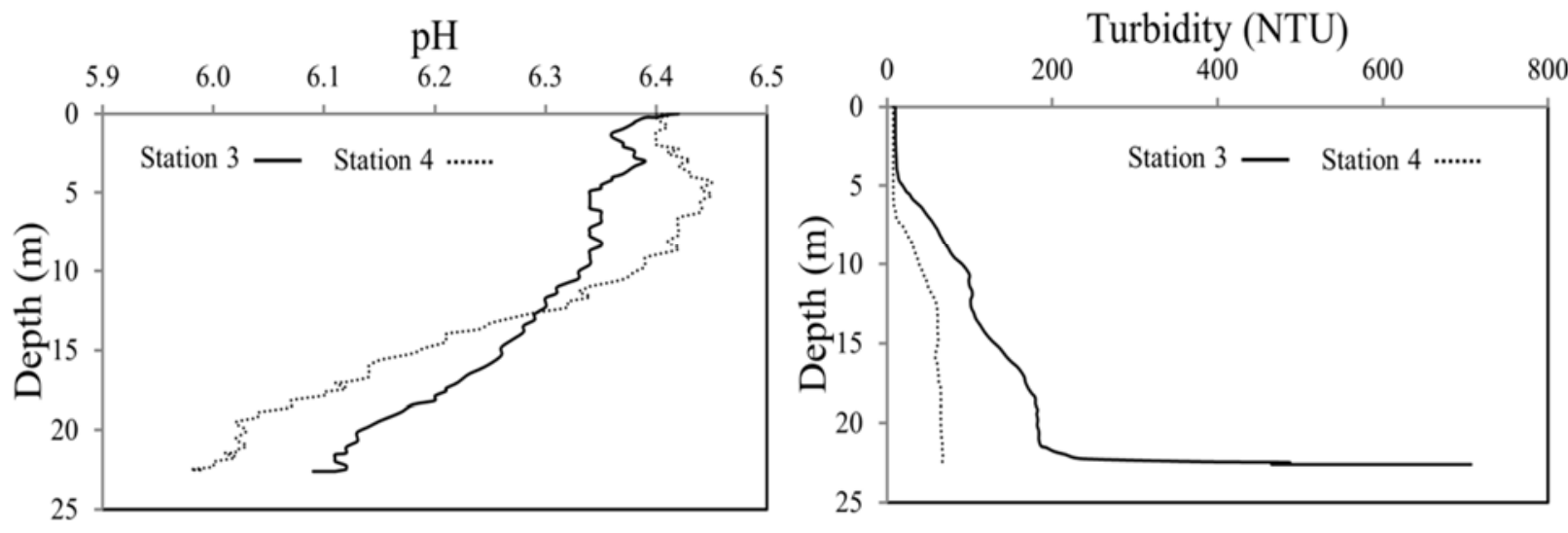

Figure 4. Depth profile of $\mathrm{pH}$ and turbidity in station 3 (solid line) and station 4 (dot line) which are located at Murum River in Bakun reservoir in November 2013.

The nutrient level in the Bakun reservoir was found to vary at different parts and depths of the reservoir. Station 1 and 2, which are located at Batang Balui and Linau River, were grouped together as Cluster 1 as illustrated in Figure 5. The grouping of the two stations under the same cluster suggests that the two stations showed similar water characteristics where both stations contained high $\mathrm{BOD}_{5}$ concentration and are classified as Class IV, which does not meet the requirement of aquatic species according to the NWQS.

On the other hand, all water depths at Station 5 examined were grouped together as Cluster 3 as the sites were found to contain high $\mathrm{NO}_{2}{ }^{-}-\mathrm{N}$ and TP concentrations. Station 4 at a depth of 20 $\mathrm{m}$ was grouped as Cluster 5 as it showed a peak value of OKN concentration. Meanwhile, deeper water columns at Station $3(10 \mathrm{~m}$ and $20 \mathrm{~m}$ ) were grouped together as Cluster 2. Shallower water columns at Station 3 and 4 were grouped as Cluster 4 indicating that the Murum dam construction could have an impact on both stations, which received water from the upstream of the construction site.

\section{CONCLUSION}

Generally, there is an indication of organic pollution with high $\mathrm{BOD}_{5}$ and $\mathrm{OKN}$ concentrations in the Bakun reservoir. The nutrient level in the Bakun reservoir varied spatially and changed as water depth increased. Station 1 and 2, which are located at Batang Balui and Linau River, contained higher $\mathrm{BOD}_{5}$ concentration and are classified as Class IV according to the NWQS. Station 3 and 4, which are located at the downstream of the Murum dam construction site, contained higher $\mathrm{NO}_{3}{ }^{-}-\mathrm{N}$ concentration compared to other stations but the concentration still complied with the standard of Class II. Besides, the highest turbidity and OKN values at a depth of $20 \mathrm{~m}$ were also observed at Station 3 and 4, respectively, indicating the impact of the Murum dam construction on the downstream river. Station 5 , which is located near to the dam, contained high $\mathrm{NO}_{2}^{-}-\mathrm{N}$ and TP concentrations but low $\mathrm{NO}_{3}^{-}-\mathrm{N}$ and $\mathrm{OKN}$ concentrations. 


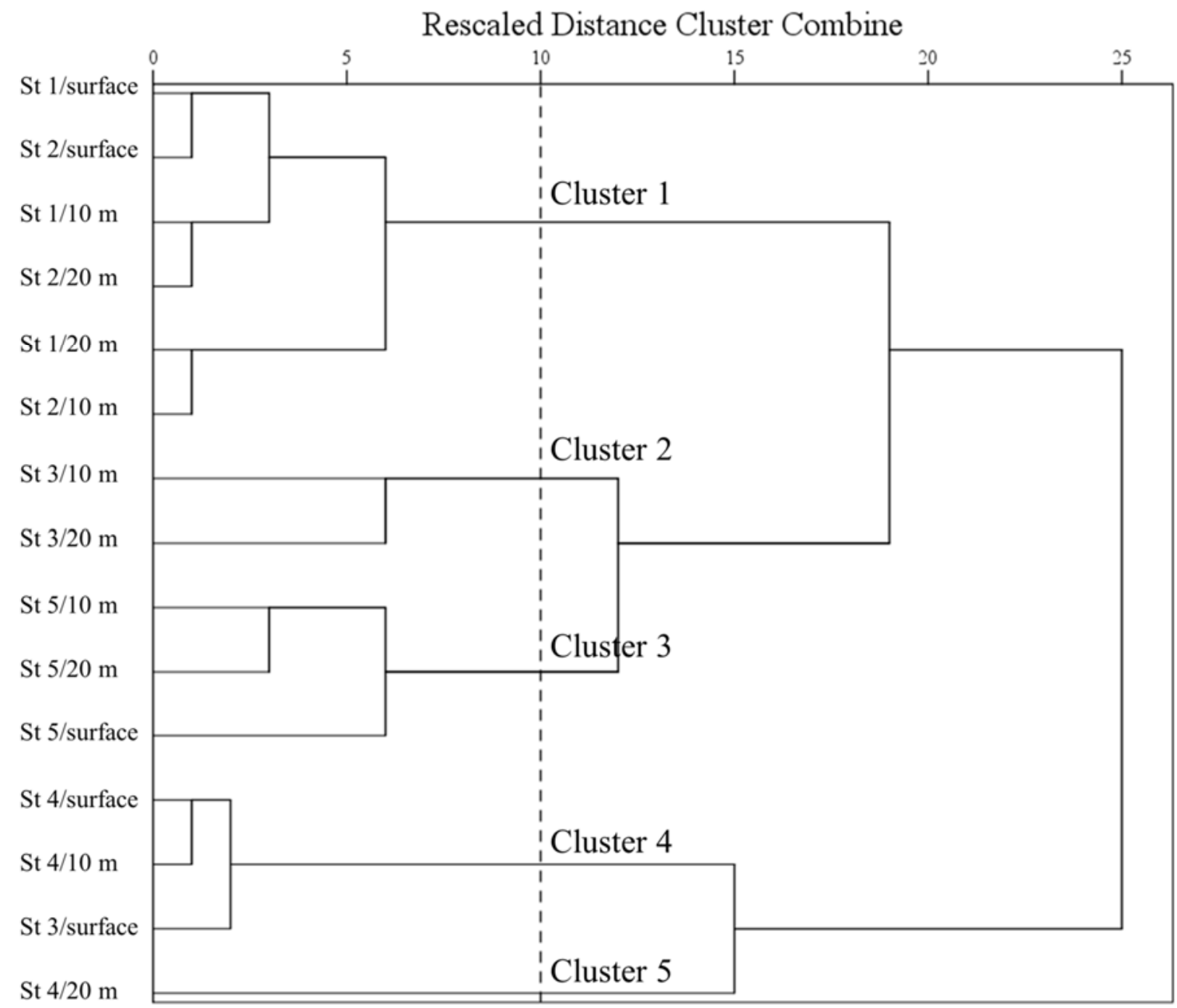

Figure 5. Clusters of the five sampling stations located in the Bakun reservoir at three different depths (surface layer, $10 \mathrm{~m}$ and $20 \mathrm{~m}$ ) in Sarawak, Malaysia.

\section{ACKNOWLEDGEMENT}

The authors appreciate the financial support provided by the Malaysian Ministry of Higher Education through Grant No. FRGS/STWN01(04)/991/2013(32), and the facilities provided by Universiti Malaysia Sarawak.

\section{REFERENCES}

Aris, A.Z., Lim, W.Y., Praveena, S.M., Yusoff, M.K., Ramli, M.F. \& Juahir, H. (2014). Water quality status of selected rivers in Kota Marudu, Sabah, Malaysia and its suitability for usage. Sains Malaysiana, 43(3): 377-388.
Camargo, J.A. \& Alonso, A. (2006). Ecological and toxicological effects of inorganic nitrogen pollution in aquatic ecosystems: a global assessment. Environment International, 32(6): 831-849.

Camargo, J.A., Alonso, A. \& Salamanca, A. (2005). Nitrate toxicity to aquatic animals: a review with new data for freshwater invertebrates. Chemosphere, 58: 1255-1267.

Das, P.C., Ayyappan, S., Das, B.K. \& Jena, J.K. (2004). Nitrite toxicity in Indian major carps: sublethal effect on selected enzymes in fingerlings of Catla catla, Labeo rohita and Cirrhinus mrigala. Comparative Biochemistry and Physiology Part C, 138(1): 3-10. 
Department of Environment. (2015). Malaysia environmental quality report 2014. Kuala Lumpur, Malaysia: Department of Environment.

Hach. (2015). Hach water analysis handbook. USA: Hach Company.

Hamlin, H.J. (2006). Nitrate toxicity in Siberian sturgeon (Acipenser baeri). Aquaculture, 253: 688-693.

Hayami, Y., Ohmori, K., Yoshino, K. \& Garno, Y.S. (2008). Observation of anoxic water mass in a tropical reservoir: the Cirata Reservoir in Java, Indonesia. Limnology, 9(1): 81-87.

Jenkins, D., Connors, J.J. \& Greenberg, A. E. (2005). Standard methods for the examination of water and wastewater. 21 st ed. Washington, DC: American Public Health Association.

Jensen, F. B. (2003). Nitrite disrupts multiple physiological functions in aquatic animals. Comparative Biochemistry and Physiology Part A, 135: 9-24.

Ling, T.Y., Siew, T.F. \& Lee, N. (2010). Quantifying pollutants from household wastewater in Kuching, Malaysia. World Applied Sciences Journal, 8(4): 449-456.

Ling, T.Y., Debbie, D.P., Lee, N., Norhadi, I. \& Justin, J.J.E. (2012). Water quality at Batang Ai Hydroelectric Reservoir (Sarawak, Malaysia) and implications for aquaculture. International Journal of Applied Science and Technology, 2(6): 23-30.

Ling, T.Y., Lee, T.Z.E. \& Nyanti, L. (2013). Phosphorus in Batang Ai Hydroelectric Dam Reservoir, Sarawak, Malaysia. World Applied Sciences Journal, 28(10): 1348-1354.

Ling, T.Y., Nyanti, L. \& John Masion, A.S. (2015). Water quality of rivers that flow into Bakun Hydroelectric Dam Reservoir, Sarawak, Malaysia. ESTEEM Academic Journal, 11(Special Issue 1): 9-16.

Ling, T.Y., Nyanti, L., Muan, T., Grinang, J., Sim, S.F. \& Mujahid, A. (2016). Physicochemical parameters of Bakun Reservoir in Belaga, Sarawak, Malaysia, 13 months after reaching full supply level. Sains Malaysiana, 45(2): 157-166.
Ling, T.Y., Soo, C.L., Liew, J.J., Nyanti, L., Sim, S.F. \& Grinang, J. (2017). Influence of Rainfall on the Physicochemical Characteristics of a Tropical River in Sarawak, Malaysia. Polish Journal of Environmental Studies, 26(5): 2053-2065.

Muangthong, S., \& Shrestha, S. (2015). Assessment of surface water quality using multivariate statistical techniques: case study of the Nampong River and Songkhram River, Thailand. Environmental Monitoring and Assessment, 187(9): 1-12.

Nyanti, L., Ling, T.Y. \& Grinang, J. (2012a). Physico-chemical characteristics in the filling phase of Bakun Hydroelectric Reservoir, Sarawak, Malaysia. International Journal of Applied Science and Technology, 2(6): 92 101.

Nyanti, L., Hii, K.M., Norhadi, I. \& Ling, T.Y. (2012b). Impacts of aquaculture at different depths and distances from cage culture sites in Batang Ai Hydroelectric Dam Reservoir, Sarawak, Malaysia. World Applied Sciences Journal, 19(4): 451-456.

Nyanti, L., Ling, T.Y. \& Muan, T. (2015). Water quality of Bakun Hydroelectric Dam Reservoir, Sarawak, Malaysia, during the construction of Murum Dam. ESTEEM Academic Journal, 11(1): 81-88.

Rabalais, N.N. (2002). Nitrogen in aquatic ecosystems. Ambio, 31(2): 102-12.

Rossel, V. \& de la Fuente, A. (2015). Assessing the link between environmental flow, hydropeaking operation and water quality of reservoirs. Ecological Engineering, 85: 26-38.

Schneider, S.C., Cara, M., Eriksen, T.E., Budzakoska Goreska, B., Imeri, A., Kupe, L., Lokoska, T., Patceva, S., Trajanovska, S., Trajanovski, S., Talevska, M. \& Veljanoska Sarafiloska, E. (2014). Eutrophication impacts littoral biota in Lake Ohrid while water phosphorus concentrations are low. Limnologica, 44: 90-97.

Suratman, S., Hee, Y.Y. \& Tan, H.S. (2015). A preliminary study of the distribution of phosphorus, and silicon compounds in Tasik Kenyir, Hulu Terengganu, Malaysia. Journal of Sustainability Science and Management, 10(2): 35-41. 